\title{
ANOTASI BIBLIOGRAFI PEDAGOGI SEJARAH, NASIONALISME DAN KARAKTER BANGSA
}

\author{
Oleh \\ Heri Susanto \\ Email: iniherisusanto@ulm.ac.id \\ Program Studi Pendidikan Sejarah Fakultas Keguruan dan Ilmu Pendidikan \\ Universitas Lambung Mangkurat \\ Banjarmasin
}

Susanto, H. (2014). Seputar Pembelajaran Sejarah; Isu, Gagasan Dan Strategi Pembelajaran. Aswaja Pressindo.

Buku ini membahas tiga fokus utama yaitu; isu seputar pembelajaran sejarah yang berkembang dari di era kekinian, gagasan tentang pembelajaran sejarah untuk mencapai beberapa sasaran utama, antara lain nasionalisme, karakter peserta didik, serta aspek pedagogis lainnya yang penting dalam pembelajaran sejarah. Aspek strategi membahas secara mendalam tentang tujuan pedagogis sejarah, teknis pembelajaran sejarah mengacu pada tujuan pembelajaran sejarah, serta contohcontoh aplikatif pembelajaran sejarah.

Susanto, H. (2013). Understanding of Regional History and Perception of Cultural Diversity in Developing Nationalism. Historia: Jurnal Pendidik dan Peneliti Sejarah, 14(1), 91-100.

Artikel ini mengkaji aspek pemahaman sejarah lokal mahasiswa Program Studi Pendidikan Sejarah Fakultas Keguruan dan Ilmu Pendidikan Universitas Lambung Mangkurat dan persepsi mereka terhadap keberagaman budaya yang ada di lingkungan mereka yang digunakan dalam mengembangkan sikap nasionalisme dalam lingkup lokal. Artikel ini memberi penegasan bahwa indikator-indikator dalam pemahaman sejarah lokal ternyata memberikan kontribusi dalam membentuk sikap nasionalisme.

Susanto, H. (2015). Strategi Mengembangkan Historical Empathy dalam Pedagogi Sejarah. In Prosiding International Conference: Contribution of History to Social Sciences and Humanities (pp. 44-53).

Artikel ini mengkaji tentang prinsip dasar yang secara konseptual efektif dalam melatih historical empathy peserta didik dalam pembelajaran sejarah. Kajian dalam artikel ini menguraikan dua aspek utama historical empathy, yaitu aspek kognitif dan aspek afektif yang merupakan komponen pembentuk historical 
empathy. Berdasarkan kedua aspek tersebut, artikel ini menyajikan rumusanrumusan pedagigis dalam pengembangan historical empathy. Dalam tiap rumusan juga dikembangkan beberapa atribut yang diperlukan untuk pencapaian historical empathy.

Susanto, H. (2019). Media Pembelajaran Sejarah Era Teknologi Informasi (Konsep Dasar, Prinsip Aplikatif, dan Perancangannya). FKIP Universitas Lambung Mangkurat.

Buku ini merupakan hasil penelitian yang membahas tentang pengembangan media pembelajaran sejarah dengan menggunakan media yang berbasis teknologi mobile smartphone. Pembahasan buku ini diawali dengan penyajian konsep media pembelajaran sejarah di era teknologi informasi. Pada bagian selanjutnya disajikan prinsip-prinsip dalam mengaplikasikan media pembelajaran sejaran berbasis mobile smartphone. Selanjutnya pada bagian akhir disajikan teknis dan metodologis perancangan media pembelajaran sejarah berbasis mobile smartphone.

Susanto, H., \& Akmal, H. (2018). Efektivitas Penggunaan Aplikasi Pembelajaran Berbasis Mobile Smartphone Sebagai Media Pengenalan Sejarah Lokal Masa Revolusi Fisik di Kalimantan Selatan Pada Siswa Sekolah Menengah Atas. Historia: Jurnal Program Studi Pendidikan Sejarah, 6(2), 197-206.

Artikel ini mengkaji pengaplikasian media pembelajaran sejarah berbasis mobile smartphone dalam mengenalkan sejarah lokal, terutama untuk materi "Masa Revolusi Fisik di Kalimantan Selatan". Pembahasan dalam artikel ini menguraikan aspek-aspek aplikatif dalam penggunaan mobile smartphone dan efektivitasnya dalam memperkenalkan materi sejarah lokal. Tulisan ini menyajikan aspek metodologis dan teknis penggunaan media pembelajaran sejarah di era teknologi informasi. Berdasarkan pembahasan dalam artikel ini diketahui bahwa penggunaan mobile smartphone efektif dalam memberikan pemahaman dan pengenalan materi sejarah lokal kepada peserta didik pada level sekolah lanjutan atas.

Susanto, H. (2017). Perception on Cultural Diversity and Multiculturalism Education. In 1st International Conference on Social Sciences Education-" Multicultural Transformation in Education, Social Sciences and Wetland Environment"(ICSSE 2017). Atlantis Press.

Artikel ini merupakan conference paper yang membahas tentang penggunaan persepsi terhadap keberagaman budaya dalam pendidikan multikulturalisme. Pembahasan dalam artikel ini menitikberatkan pada keberagaman budaya sebagai landasan dalam pendidikan multikulturalisme. Ide yang dikembangkan dalam artikel ini adalah menjadikan persepsi positif terhadap keberagaman budaya sebagai pintu masuk dalam pendidikan multikulturalisme. 
Heri, S. (2014). Implementasi Kurikulum 2013 dan Tantangan Pembelajaran Saintifik Bagi Guru Sejarah.

Artikel ini merupakan telaah konseptual tentang implementasi Kurikulum 2013 berkaitan dengan peran guru sejarah dalam melaksanakan pembelajaran saintifik. Dalam pembahasan artikel ini diuraikan beberapa tantangan mendasar yang dihadapi guru pada umumnya dan guru sejarah pada khususnya dalam melaksanakan pembelajaran dengan menggunakan kurikulum 2013. Tinjauan dalam artikel ini merupakan tinjauan praksis pembelajaran yang dilakukan guru sejarah dalam implementasi Kurikulum 2013.

Heri, S. (2014). Kemampuan Berfikir Kritis dalam Pedagogi Sejarah Sebagai Upaya Membangun Karakter Peserta Didik.

Artikel ini memberikan analisis konseptual tentang praksis pedagogis yang dapat dikembangkan dalam upaya pendidikan karakter. Pembahasan dalam artikel ini menitikberatkan pada pengembangan kemampuan berpikir kritis peserta didik sebagai bentuk pengembangan nilai karakter. Pola berpikir kritis dalam kajian ini merupakan aspek karakter yang dapat dikembangkan dalam pembelajaran sejarah baik di tingkat sekolah menengah maupun di perguruan tinggi.

\section{Simpulan Konseptual Anotasi Bibliografi}

Nasionalisme merupakan tujuan penting dari pendidikan sejarah. Untuk mencapai hal tersebut banyak cara dilakukan, antara lain dengan melakukan perubahan kurikulum. Perubahan kurikulum adalah sebuah keharusan, dan sebagai konsekuensinya semua pihak harus mengikuti ketentuan yang berlaku terkait perubahan kurikulum. Sejumlah persoalan baru yang menyertai perubahan kurikulum barangkali akan terus bermunculan, satu yang pasti dikehendaki atau tidak, perubahan zaman akan membawa berbagai konsekuensi, termasuk perubahan kurikulum. Langkah sederhana dan nyata yang dapat dilakukan oleh guru adalah upaya membekali diri dengan kemampuan mengajar yang lebih baik serta meng-implementasikannya dalam pembelajaran yang dilakukan.

Kurikulum terbaru dalam sistem pendidikan nasional berlandaskan pada teori konstruktivisme. Konstruktivisme menekankan pada dikuasainya keterampilan siswa untuk menemukan dan membangun pengetahuan mereka sidiri. Kelas konstruktivis pada dasarnya merupakan kelas, dimana siswa mampu melakukan aktivitas belajar dengan cara menemukan/membuat perspektif-perspektif baru dalam pemahaman mereka terhadap peristiwa sejarah sebagai hasil dari pengolahan informasi yang mereka lakukan, bukan keterpaksaan untuk memahami kebenaran informasi yang diberikan oleh guru. Keterampilan yang semestinya diajarkan dengan pendekatan konstruktivisme adalah 
kemampuan berpikir historis. Aspek selanjutnya yang penting untuk dikembangkan dan merupakan sintesis dari kemampuan berpikir historis adalah historical empathy. Dengan mengembangkan keduanya, secara metodologis pembentukan nasionalisme peserta didik dapat dilakukan secara sistematis dan terstruktur.

Pengembangan pedagogi sejarah untuk melatih historical empathy, diperlukan untuk memperdalam kemampuan akademik siswa dalam mempelajari sejarah dan membangun keterikatan emosional siswa dengan masa lalu, sehingga siswa dapat melakukan interpretasi dan memahami makna dari peristiwa masa lalu. Berbagai alternatif model pembelajaran dapat digunakan untuk melatih historical empathy, selain itu berbagai media juga dapat digunakan untuk memperkuat pemahaman siswa dan membangun empati dari peristiwa sejarah. Berbagai bibliografi di atas memberikan beberapa tinjauan yang dapat menjadi awal pengembangan pembelajaran sejarah di sekolah maupun di perguruan tinggi untuk mencapai tujuan pembelajaran sejarah. 